Island Studies Journal, Vol. 12, No. 1, 2017, 187-206

\title{
Reiterating the boundary: community discourse in light of proposed technological change on Vinalhaven Island, Maine, USA
}

Jessica E. Brophy

Bridgewater College, Virginia, USA

jbrophy@bridgewater.edu

\begin{abstract}
This qualitative work is a case study of Vinalhaven, a small Maine island, and its negotiation of the intersection of technology use, space, place, and identity. Using a phenomenologically informed theoretical approach coupled with a version of Foucault's archaeology of discourse $(1972,1994)$ as a method of analysis, the role of place and space is explored in the context of a bounded community's public discussion about whether or not to build a cell phone tower on the island. In opposition to the oft-cited narrative of technology-asconnective-panacea, the discourse of the community surrounding the potential technology serves to complicate the community's expression of its boundaries. If anything, the potential introduction of a new form of connectivity for the island community prompts a reaffirmation and re-articulation of the community's boundaries, its sense of self, and its experience of isolation. The case study offers insight into approaches to the introduction of connective technologies and infrastructures in island communities, thus extending both place-based theories of technology and the depth of island studies.
\end{abstract}

Keywords: Boundedness, community identity, insularity, Maine, technology

https://doi.org/10.24043/isj.12

(c) 2017 - Institute of Island Studies, University of Prince Edward Island, Canada.

\section{Introduction}

Proposed cell phone service on the Maine island of Vinalhaven in 2001 represented a substantial change to connectivity, physical and social mobility patterns. Such changes are of interest in and of themselves; yet the relationship between those potential changes and the place of the island within its public discourse reveals as much about the place-related values and concerns of the various stakeholders as it does about the potential impact of the technology. Changes in communication technologies are often construed as transformative, in terms of place and boundary permeation. Much can be learned about space, place, and technology use from the ways in which people talk about (and don't talk about) technology.

This study investigates how an island community articulates place in relation to proposed shifts in technology. The discourse involves multiple elements of boundary marking and boundary making, the development of spatial narratives of belonging and the articulation of concerns about contamination or loss of purity. In the end, the analysis of the discourse reveals concerns based not on the physical actualities of the technology and the spaces it would serve to connect, but rather on social potentialities surrounding the 'kind of' place Vinalhaven is imagined to have been, is, and will/should be. 
Vinalhaven is a 17.4-hectare island, home to some 1,200 residents, located in Knox County, in the US state of Maine. As an island community, it is geographically bounded, a microcosm of larger society. Its residents experience heightened, visible insularities and connectivities; that is, the island is accessible via ferry, charter, or personal flight or boat only; yet, the island offers most contemporary communication technologies to its residents. Its population can swell to more than 5,000 during the peak summer months. This means that as a bounded island community, Vinalhaven regularly experiences a large influx of people. Some of these visitors or summer residents are fully integrated into the community and part of its identity; others are tourists seeking a brief and specific experience. Thus, the community regularly undergoes both a heightened sense of islandness and boundary permeations; its public discourse and community identity are attuned to both aspects.

In early 2001, Paul Strout of Tower Specialists, based in Falmouth, filed a planning board application on behalf of property owners William and Joy Mills of Vinalhaven for the construction of a 58-meter-tall cell phone tower. Cell phone service on the island scarcely exists; indeed, cell service along the coast of Maine is notoriously spotty because of the hilly terrain and interference due to large amounts of granite. The discussion prompted a revision of Vinalhaven's zoning ordinances, several public hearings, and heated exchanges in the not-forprofit community circular, The Wind. Eventually, the planning board issued a permit for the proposed cell phone tower. However, due to the several-month delay and to the substantial costs of erecting the tower in question, neither Unicel (now owned by Verizon Wireless) nor U.S. Cellular were willing to build the tower at that time. No cell phone tower has yet been built on Vinalhaven despite the controversy and its resolution.

The discourse surrounding the proposed cell phone tower was gathered and analyzed according to a modified version of Foucault's archaeology of discourse (1972), as refined by Chay-Nemeth (2001) and adapted to the layered and diverse statements of a particular crosssection of stakeholders in regards to the cell phone tower issue.

\section{Literature review}

\section{Islands and the study of spaces}

Island studies, as a field, foregrounds the physical conditions of islands as emphasizing spaces and particularly boundaries; that is, those elements that exist in all environs but are highlighted on islands (McCall, 1994; 2002; Persoon \& Osseweijer, 2002). 'Islandness' indicates the particular form of boundedness and geographic isolation inherent to islands. To be an islander is to inhabit an island space: a space that is detached and isolated geographically, and often also culturally and socially. Islands are often seen to promote a strong, shared community identity and common experience (Baldacchino, 2005; Fitchen, 1991; Mackenzie, 2004). However, that same islandness is often employed as a way to denigrate or belittle island community life and experiences as insular, 'backward', or otherwise inferior to mainland culture and experiences (Gillis, 2004). The heightened community awareness of insularity highlights the potential for the permeation of boundaries and boundedness to be construed as a threat (Douglas, 1966). As technologies (whether digital communication technologies, transportation technologies, or other infrastructure) increase the openness of a community and its boundary permeations, such boundary permeations may be construed as boundary transgressions. Thus, the technology itself may be framed as a threat to the community, particularly to the community's identity and sense of place. Yet, simultaneously, boundary permeations are recognized as necessary for the health, 
vibrancy, attractiveness, and continued existence of (especially island) communities (see the discussion of accessibility and islands in Karampela et al., 2014). Place, as it relates to island identity, is locked in an uneasy tension between openness and closure, connectedness and isolation.

Understanding space as relational and unfolding means acknowledging space as a process (Grosz, 2001; Massey, 2005). Through that process, the bodily habitation and creation of space, there is an emergence of identities. These 'spatial identities' constitute place. Place is an emergent property of the bodily habitation of space and therefore examining place illuminates what Hay (2006, p. 31) refers to as "human attachment". Such attachment may be deepened by the particular experience of space; indeed, Hay (2006, p. 31) argues that the heightened experience of boundedness in islands lends a particular weight to the 'human attachment' to island spaces:

Islands-real islands, real geographical entities-attract affection, loyalty, and identification. And what do you get when you take a bounded geographical entity and add an investment of human attachment, loyalty, and meaning? You get the phenomenon known as 'place'. Islands are places - special places, paradigmatic places - topographies of meaning in which the qualities that construct place are dramatically distilled.

The 'boundedness' of an island is actually constructed through its connectedness. "Connectedness describes the island condition better than isolation, whilst that apparently emphatic boundary is the most permeable of membranes" (Hay, 2006, p. 23). The permeability of the boundary is both necessary to place and a potential threat. The permeation of boundaries offers depth to approaching "island meanings", which "divergent or convergent, emerge from a deeply visceral lived experience" (Hay, 2006, p. 34). These productions of meaning-making mark islands as places.

Massey (2005, p. 179) understands space as "continually shifting in its construction, being renegotiated". This process of 'renegotiation' becomes emphasized in relation to boundaries. How, why, and whether spaces are open and/or closed are not sufficient questions to ask. Spaces become places invested with meaning because of these processes of negotiation about and around boundaries. As Massey (2005, p. 179) notes:

The real socio-political question concerns less, perhaps, the degree of openness/closure [...] than the terms on which that openness/closure is established. Against what are boundaries erected? What are the relations within which the attempt to deny (and admit) entry is carried out? What are the power-geometries here; and do they demand a political response?

This space-as-process-of-meaning-making drives the investigation of Vinalhaven community members' discourse surrounding technology use and the ways in which isolation and connectivity imbue the rhetoric employed by residents. The boundaries on Vinalhaven are more than the physical boundary between the sea and the land. Other boundaries include those between the island and the mainland, which can be understood in multiple ways as physical, cultural, and socio-economic (see Lewis, 1993, 1998; Karampela et al., 2014). There are also the internal boundaries between year-round residents and seasonal residents or visitors, between those whose families have lived on the island for generations and those who are 'transplants' to 
the community, between the have-nots and the haves, and between the fishing industry and the tourist industry (see Thompson, 2012). Samuel McReynolds (2014) has studied the tension between and sustainability of this relationship between transplants and 'locals'. Other scholars have addressed the way in which island identity is produced, negotiated, and maintained (Gibbons, 2010; Marshall, 2009). Marshall's work, in particular, documents the minutiae of interplay between various stakeholders in an island community-minutiae that have major impacts on how the island community understands itself and operates. As she notes, in small island communities, "There are no givens, no unassailable boundaries that protect and sustain the way things have been" (Marshall, 2009, p. 362).

The specificity of islands and the production of island meanings - its unique 'place'relates to its boundedness and its pattern of organization through and with boundaries. Thus, the meaning of islands is bound up with the intersubjective experience and creation of islands as bounded yet connected. There are elements of islandness that distinguish it from mainland places or spaces; yet these distinct elements are constantly re-created through the experience of island spaces.

\section{Rhetoric and Foucault's archaeology of discourse}

We have established that space and place carry weight and meaning, certainly for insular communities such as islands. The challenge is how to access that meaning in a scholarly way. One solution is to examine the community's public discourse. Foucault's (1972) archaeology offers a theoretical and methodological approach to examining the patterns and rules through which a discourse produces objects. These objects - such as the potential cell phone tower, or, in Foucault's case, madness or psychopathy-are discussed in ways that create and structure meanings.

A discourse is often defined by what it excludes and rejects; though objects change over time, relations between objects ( $\mathrm{X}$ is $\mathrm{X}$ because it has $\mathrm{A}$ and $\mathrm{B}$ but not $\mathrm{C}$ ) tend to remain stable. Foucault's (1972, p. 46) discussion of "the group of figures" of psychology in The Archaeology of Knowledge raises this point:

We sought the unity of discourse in the objects themselves [...] and what we discover is neither a configuration, nor a form, but a group of rules that are immanent in a practice, and define it in its specificity.

In order for an object to be knowable, it conforms to the groups of relationships established; such established relationships are often revealed in moments of conflict. If we want to know about the construction of Vinalhaven as an object of discourse, we can investigate the discursive relationships that allow phenomena to be knowable; the articulated discourse surrounding the potential cell phone tower offers such a moment.

Foucault is particularly interested in which speakers are granted legitimacy and authority (doctors, scientists), the sites from which they speak (hospitals, laboratories), and the various positions they occupy. These positions include perceptual subjectivities; that is, in relation to an object such as 'madness' they can be a listening subject or an observing subject. In this sense, the discourse of concern - created by individuals but representative of broader subject positions and webs of rules - is not considered a 'phenomenon of expression'. As Foucault (1972, p. 55) says: 
Discourse is not the majestically unfolding manifestation of a thinking, knowing, speaking subject, but on the contrary, a totality, in which the dispersion of the subject and his discontinuity with himself may be determined. It is a space of exteriority in which a network of distinct sites is deployed.

Thus, archaeology is less concerned with the autonomous subject as a source of thought and more concerned with the various constraints and freedoms allowed to the speaking subject: that is, the regulation of what is sayable for a subject by the totality of the discourse. The interest here is in understanding the positions and categories of speakers rather than the specific persons themselves.

Examining multiple, overlapping discourses establishes a grid of possible subjectivities. Looking at a snapshot of a particular discourse at a particular time for a particular community can help illustrate what is sayable and knowable for different categories of speakers involved in a community. This project holds that places develop their own grid of subjectivities, their own series of patterns of statements. While technological changes may appear abstract and devoid of place, each develops in a place-specific context and each technology enters into an extant, complex web of technologies.

The goal of this study is to offer a local, specific answer to the question: how does place matter in the digital age? More specifically, in which ways does the discourse surrounding a proposed cell phone tower relate to the negotiation of an island community's boundary, and that boundary's relationship to its articulation of place?

\section{Methodology}

When I use the term 'negotiation of', I mean it as shorthand for: permeation of, recognition of, definition of, dismissal of, or reference to place and boundedness. The phrase is purposefully vague to allow various patterns to emerge from the discourse, rather than parsing the discourse with a particular outcome in mind.

Identity in this context is that particular, public articulation of self that is made possible by the spaces subjectivity allows. Thus, attending to the discursive environments in which Vinalhaven residents construct their identities is important for the construction of community identity but also to the larger project of understanding how these identity constructs relate to the production of place and the experience of space within a community.

In other words, because I am interested conceptually in the regulation of a community's place identity as it is articulated through discourse surrounding technology use, I employ an archaeology designed to uncover the rules and patterns of identity production in this discourse. This archaeology is based on Foucault's $(1972,1994)$ archaeology and explores the ways in which the concepts of place, space, boundedness, and connectedness are articulated and are knowable in and at the crux of community identity and technology. The goal of an archaeology is to uncover the rules and structures that constrain what is possible in language. Foucault examines existing statements and considers in which ways they matter and regulate "what is taken seriously at any given period, and to defend it, criticize it, and comment upon it" (Dreyfus \& Rabinow, 1983, p. 52).

This project models a method similar to Chay-Nemeth's (2001) work on HIV/AIDS in Thailand, which employed a version of Foucault's archaeology. Chay-Nemeth uses four categories of archaeological analysis to better understand the development of distinct publics 
related to the HIV/AIDS crisis in Thailand: the formation of objects, the formation of enunciative modalities, the formation of concepts, and the formation of strategies.

For the purposes of this project, the unit of analysis is the statement, or Foucault's 'enonce'. The statement is not an utterance or a sentence or a grammatical bit, but rather a contextualized and inter-related "atom" of discourse and is the "central theme" of discursive analysis (Foucault, 1980). As Dreyfus and Rabinow (1983, p. 45) note:

The statement is not even a grammatical entity restricted to sentences. Maps can be statements if they are used as representations of a geographical area, and even a picture of the layout of a typewriter keyboard can be a statement if it appears in a manual as a representation of the way the letters of a keyboard are standardly arranged.

The statement, then, might be a photograph (such as a photograph of a ferry boat or a pedestrian line-up for boarding) or a literal sign (such as those directing traffic at the ferry landing) or other visuals (such as the striking presence of the newly constructed 400 -foot windmills, about more of which below). In terms of 'traditional' texts or transcribed accounts, a statement might be a sentence, a reiterated phrase, a reference to a metaphor, or even a pattern of speaking.

Three sets of data were collected. First, documents available at the Vinalhaven town hall archives and the historical society archives were gathered. This involved examining all archival documents of the historical society from 1999 to 2009, focusing particularly on all available copies of the community's circular, The Wind. This not-for-profit community circular is published by a group of volunteers, headed by local resident Sue Radley. It is financed by small fees to publish advertisements or announcements. Other documents consulted were collected and archived by the historical society, including newspaper articles and personal photos and documents. These were sorted into files based on subject; I read through several files on relevant subjects, copying all materials relevant to the topic. The town hall supplied meeting notes, agendas, and other public documents relating to the cell phone tower controversy in 2001.

The second data set was collected during a series of field trips to Vinalhaven from March to October of 2009. Four in-depth interviews, and some casual interviews, were conducted. Of those interviewed, two were members of town governance, one was a long-time employee of the ferry service, and one was a local business owner.

The third data set is a collection of participant-observations, styled after the anthropological method of ethnography. These elements included detailed field notes and physical observation. This data set is meant to supplement the first two and offer a form from which to spatially narrate the project as a whole.

I then identified statements about Vinalhaven as a place with regard to the construction of the cell phone tower, and I set those statements in a larger universe of statements that form a delimited 'system'. Such a system is marked by the regularity:

between objects, types of statements, concepts, or thematic choices [...] [marking] an order, correlations, positions and functionings, transformations. (Foucault, 1980, p. 41)

The regularities evinced particular functions. Through an iterative process of reading, rereading, sifting, and re-sifting, themes and patterns emerged from the statements. These were analyzed in terms of Chay-Nemeth's four axes. 
I have my own experiences with Maine islands. I was raised on Deer Isle, an island in the same bay as Vinalhaven. I also worked for more than a decade as a newspaper reporter in that community, writing about the intricacies of municipal government and resource management on the island. My maternal grandmother was born on Vinalhaven (in fact, while researching at Vinalhaven Historical Society, I came across a distant and previously unknown relative volunteering there). As such, I bring to this research my own deep and subjective history as an islander.

\section{Analysis}

The formation of objects

Chay-Nemeth (2001) identifies three rules formation for discursive objects: first, where (on what surfaces) the object emerges. Second, which authorities "delimit the grid of specification for the object's ontology" (Chay-Nemeth, 2001, p. 134). That is, who or what legitimates the object and what elements define the object. Third, in what ways does this "grid of specification" enable or limit the object and how it is used. Members within groups exclude in nominal if not more active and forceful ways; such acts of exclusion require and reinforce secure boundaries. Assuring the security of boundaries entails the calculation of risk, assessment of danger, and avoidance of crisis (Foucault, 2007, p. 61). Though Foucault parsed these concepts in relation to the bureaucracy of government response to endemic diseases, they are relevant to the current study on a more local and specific scale: the processes mirror those of self-protection in an island community.

There are two surfaces of emergence of particular interest to this analysis. Though these two surfaces do not exhaust the surfaces of emergence, they do illustrate many of the concepts, concerns, and issues at stake within the discourse and the process of object formation. First is the naming of boundaries, some developed by the discourse, others defended in or invoked by the discourse. For example, established relationships and patterns of speaking reveal demarcations between the island and the mainland as well as between locals and non-locals. These boundaries draw into the discourse many concepts and satellite social values such as selfsufficiency and community sovereignty.

Second, the cell phone tower as an unnatural or invasive entity develops a more specific discursive relationship between 'Vinalhaven-ness' and a 'natural purity' or wholeness. Upon this surface, the fears of "contamination" (Douglas, 1966) of Vinalhaven by the trappings of the 'urban' or the 'mainland' is articulated in a way parallel to concerns of local Vinalhaven residents about the contamination of the local culture by 'people from away'.

\section{Boundary development and policing}

The controversies surrounding the cell phone tower included visual and environmental pollution, the loss of island uniqueness, and the role of such technology in daily island life. Many year-round residents of the island, though not all, described a cell phone tower as a positive development for the community; a development that would allow for greater safety in terms of communication with lobster fishing vessels in the waters surrounding Vinalhaven and better communication in instances of emergencies. Overall, many locals characterized the cell phone tower as a general improvement to life in terms of connecting, both between island residents, and between residents and those on the mainland. Many summer residents wrote and talked about the potential cell tower as an invasion or pollution. For example, summer resident 
Alexandra Lamprecht (2001, emphasis in original) wrote in The Wind, "antennas on MR. Strout's tower will SERVE THE MAINLAND as well as the island, but the island bears all the negative effects while MR. Strout makes the money?" These concerns around 'negative effects' were primarily visual; as McCabe (2001) writes in her letter to the planning board in opposition to the tower, "Are there any provisions for making the tower aesthetically pleasing?" In her letter of opposition to the planning board, Carole MacQuestion (2001) refers to cell phone towers as a "type of clutter" and expresses fears about "the destruction of the aesthetic quality of the area".

While the divide between those for and those against the cell phone tower was not necessarily firmly split between year-round residents and summer residents and visitors, much of the public discourse was. For instance, some of the statements regarding the cell phone tower found in the register of local public documents explicitly connect the need for a cell phone tower to Vinalhaven as a bounded community of year-round residents, and that community's sovereignty:

If the islanders don't take a stand soon, Vinalhaven like many other Maine places, will become a service island where we end up cleaning the houses, serving meals, and catering the parties of the summer people!! Ugh. (Brown \& Brown, 2001)

Such statements reveal several issues for stakeholders: in this case, the sovereignty of the local community in terms of self-determination, and the explicit issue of class.

In this letter published in The Wind, the Browns write that the "debate over a cellular phone tower should never have occurred" because the island needs the cell tower as a matter of public health and safety. The note unambiguously promotes a certain type of island resident as the 'authentic' or important type, and other types of island residents as less so. Year-round residents are privileged in such a way as to discount the input of summer residents or visitors:

As for the numerous complaints by the summer population, we suggest this: the people who have their primary residence somewhere other than Vinalhaven [should] be severely limited in their participation in policy making input concerning the overall welfare of the people of Vinalhaven. Their taxes are gladly accepted, but diluting and potentially altering the way of life on Vinalhaven is not their prerogative. (Brown \& Brown, 2001)

There is nothing subtle in this piece's attempts to maintain the boundary of the island; it polices against infringements on islander sovereignty by 'outsiders'. As the community considers adopting the technology of the cell phone tower, ostensibly connecting with the mainland in a new way, some community stakeholders react by reaffirming and entrenching extant boundaries.

The patrolling, policing, and disciplining of boundaries by various groups and group members does not necessarily reflect the fears of the technology itself, but rather group members' fears surrounding the permeation of boundaries. For the Browns, loss of sovereignty of the 'real' Vinalhaven community to summer residents must be guarded against. For others, carefully managing and allotting island resources without benefit to (or aid from) the mainland is significant. Both evidence the role of boundary maintenance; as the discourse defines "what it is talking about, [giving it] the status of an object; and therefore of making it manifest, 
nameable, and describable" (Foucault, 1972, p. 46), it reasserts or reaffirms the various boundaries.

\section{Invasion of technology}

As the discourse surrounding the proposed cell phone tower developed, public expression of the perceived role of technology in relation to the place of Vinalhaven also developed. Some discussed the proposed cell phone tower as an unwelcome intrusion of mainland technology as well as an unnatural disruption of Vinalhaven's pastoral beauty. Those who raised these concerns consistently portrayed Vinalhaven's pure and untarnished beauty as synonymous with Vinalhaven itself, constructing the cell phone tower as 'non-native' or 'invasive'. This constructed Vinalhaven as a place safe from or pure of many of the technological trappings of the mainland. The fascination with this purity illustrates a facet of social class distinction within the discourse; those who fear the invasion of mainland technology on the island consider the island a refuge from the 'real world' where 'real life' takes place. The qualitative difference expressed between islanders and non-islanders is linked to material realities; year-round residents are less mobile, both in their residency and also in their economic means (Hall \& Muller, 2004). Viewing Vinalhaven as a pure respite from the 'real' world is a privilege afforded only to those who can easily and voluntarily choose to stay or leave on the island. Mobility often requires a certain level of income (Hall, 2005; Hall \& Williams, 2008). Much of the tension surrounding the development of coastal Maine breaks along socioeconomic lines (Lewis, 1993).

The importance of the nature of the island comes into play in several different forms for various stakeholders. Douglas (1966, p. 85) investigates the rituals and practices surrounding dirt and cleanliness, and finds the processes by which people organize their lives into categories or areas of clean/unclean are not about science and hygiene, but rather deeper meanings and fears: "We are separating, placing boundaries, making visible statements about the home we are intending to create out of the material house". Thus, as the threads of the discourses invoke, create, maintain, or question boundaries, the analysis must ask what value systems organize and underpin the boundary creation. What fears and values are organizing concerns regarding the cell phone tower as an invasive, non-native technology, as a potential contaminant?

Summer resident Micki McCabe wrote a letter to the planning board about the proposed tower, giving voice to several of the fears and concerns about the encroachment of a mainland technology on the island. McCabe notes that the new tower would be an "eyesore as well as detract from the natural beauty of the tree line". More specifically, she points out, the tower (which was assumed at that time to include a light at the top) "would also detract from viewing the stars in the evening [...] for those of you who are fortunate enough to live on the island yearround this may be no 'big deal' but for those of us who come to the island to enjoy the peace serenity and natural beauty of the island; this is a big deal" (McCabe, 2001).

McCabe's sentiments are representative of many summer residents participating in discussion around the tower. Vinalhaven is "peace, serenity and natural beauty". As she indicates elsewhere in the letter, "off islanders come to the island for the beauty and serenity it has to offer, NOT to bring mainland values out to sea!" (McCabe, 2001). In other words, Vinalhaven's value as a place is linked to its detachment from the 'real world' of the mainland. Part of that island quality is the lack of technological access as well as physical access.

As the analysis unfolded, it became clearer that the voices involved in the discourse could not be divided simply along a working-class/upper-class or year-round/summer resident divide; a complex amalgamation of group identities exists on the island. Social class, as a one- 
dimensional trait, does not and cannot explain the diversity and richness of an island that by most accounts (such as the U.S. Census) is remarkably homogenous. Instead, the analysis must consider the variety of identities across the spectrum of those who live year-round and those who visit. The analysis takes into account such elements as duration, type, and depth of connection to the island as a physical space.

These group identities are messy, with much overlap and disagreement on what constitutes each of the categories. Yet these categories illustrate the loose groupings of value systems and the underlying positions of authority of those involved with the discourse.

Table 1: People of Vinalhaven: Description of groups of people visiting or living on Vinalhaven.

\begin{tabular}{|l|l|l|}
\hline \multicolumn{1}{|c|}{ NAME } & \multicolumn{1}{|c|}{ DEFINITION } & \multicolumn{1}{c|}{ NOTES } \\
\hline Islander or native & $\begin{array}{l}\text { Lived on-island since } \\
\text { birth }\end{array}$ & $\begin{array}{l}\text { Definition may vary based on number of } \\
\text { generations of family's residency on } \\
\text { island }\end{array}$ \\
\hline Year-round resident & $\begin{array}{l}\text { Lives on-island year- } \\
\text { round }\end{array}$ & $\begin{array}{l}\text { Includes those who live or have lived } \\
\text { year-round on the island }\end{array}$ \\
\hline Transplant & $\begin{array}{l}\text { Moved 'from away' to } \\
\text { island }\end{array}$ & $\begin{array}{l}\text { Includes those who move to the island } \\
\text { from the mainland without blood ties to } \\
\text { an islander }\end{array}$ \\
\hline Summer resident & $\begin{array}{l}\text { Owns property on-island, } \\
\text { Lives there seasonally }\end{array}$ & $\begin{array}{l}\text { May have owned property on-island for } \\
\text { generations, or have decades-long } \\
\text { traditions of summering on-island }\end{array}$ \\
\hline Tourist & $\begin{array}{l}\text { Visits the island short- } \\
\text { term }\end{array}$ & $\begin{array}{l}\text { May be day-trippers to the island, or } \\
\text { stay for a few nights. Typically visit the } \\
\text { island once or a few times. }\end{array}$ \\
\hline
\end{tabular}

Note: This table was developed from my own studies of island lives along the Maine coast, but others have made similar taxonomies of island residents (Lewis, 1998; Gibbons, 2010).

The discourse within and among these groups on issues of importance to the community, such as that about the potential cell phone tower, produces the knowable, experienced boundaries of Vinalhaven. Indeed, de Certeau (1984, p. 123) would say that:

by considering the role of stories in delimitation, one can see that the primary function is to authorize the establishment, displacement or transcendence of limits.

Each public statement that makes up the overall discourse is a fragment of a larger story, told by a person who is part of a larger category. Class is inextricably linked to the mobility afforded to and by certain groups within that structure; yet the legitimacy of each group to speak and influence boundary determination and the production of space shifts depending on the duration and type of physical relationship with the island, as well as the discourse or boundary in question.

Vinalhaven's sense of place is primarily built on an idealized, bucolic nature; its narratives emphasize an intimacy to land and physical space. Closeness to the land is quantified by duration, with the complicating layer of property ownership (and the attendant property taxes 
levied on that property). Thus, year-round residents (particularly those who grew up on the island) are able to speak from a position of authority because of their duration - their endurance - through the off-season, the long and dark and difficult winters, the stick-to-itiveness of being in a place with limited economic opportunity and rural isolation from the mainland. Likewise, the investment of summer residents-generations of a family visiting Vinalhaven each summer, a family's second home, deep involvement with local groups or organizations - legitimizes a position of authority based on the duration of that family's time on Vinalhaven. In this vein, those who are day-trippers or brief tourists have the least authority to partake in the discussion, as their intimacy and duration with the pastoral Vinalhaven is fleeting.

\section{Formation of enunciative modalities}

This category of analysis deals primarily with the speaker or producer of discourse and those institutions that legitimatize or delegitimize that speaker. The analysis examines statements of importance linked to who the speakers are and how they relate to the discursive object, such as a planning board member discussing the proposed cell phone tower.

After the initial tower application was rejected due to zoning regulations, Vinalhaven's land use ordinance (http://townofvinalhaven.org/ordinances/Land\%20Use\%20Ordinance.1.pdf) was updated to include an 11-page section on wireless communications facilities. Contained within it are snapshots of the wider debate and controversy that surrounded the issue of the cell phone tower, solidified in the terse, formal language of documents thoroughly vetted by a lawyer.

Vinalhaven's land use ordinance revisions reveal individuals in prominent positions within the community: the town manager, a well-known businessman, and members of the planning board or the planning commission. These individuals were granted particular weight when perceiving the cell phone tower as an object, and likewise when communicating about this object within their information networks. The land use ordinance, penned by planning commission members, is the product of those authorities.

Maine law and culture trend toward self-sufficiency and self-regulation; a culture of 'that's your own business' discourages top-down management of land use. Generally resistant to state law and often belligerently skeptical of federal law, individual landowners tend to resist or rebuff as many regulations as possible (Thomas, 2011). At the same time, communities prize their ability to create local ordinances that are more restrictive than state or federal law. This creates a convoluted interrelationship; on the one hand, in rural Maine culture individual landowners resist restrictions on what they can and cannot do on their properties, and on the other hand, communities will come together and agonize over zoning language or particular planning permits. Vinalhaven itself was undergoing a comprehensive planning process during the cell phone tower controversy; that process took several years of work by individuals and community groups.

Regulations of land use are not simply an issue of policy. Rather, land use regulation codifies a discursive response to a temporally specific set of beliefs and concerns about access to and meaning of land in communities. The complex interrelationship of identity, agency (often in terms of individual or community sovereignty within boundaries), place, and space is categorized and fixed within such regulations; the continued revision, adoption, circulation, and use of such regulations indicate the dynamism of those interrelationships. The legal authority related to land use is confused by the social and political realities of the community itself. 
Therefore, when the local authorities attempt to carve out a space for local determinism, the concept of Vinalhaven as a remote, independent, unpolluted, and unique space is applied.

Consider the pressures upon Vinalhaven as an entity: the physical reality of being surrounded by an ocean and serviced by ferry (a service paid for primarily by the taxpayers and the state); the myriad of state and federal regulations (often more stringent for coastal communities due to shore land zoning requirements); the tensions between year-round and seasonal residents; the irregularity and inconstancy of the two major industries of the island (lobster fishing and tourism); and so on. The community's attempts to preserve, promote, and/or extend its agency and sovereignty are indicative of boundary marking and making processes; that is, the community's continued push to define and redefine its borders.

For example, the 'Standards for Review' (Section 11) of the Town of Vinalhaven Land Use Ordinance states:

The proposed wireless telecommunications facility shall have no unreasonable adverse impact upon designated scenic resources within the Town, as identified in the municipally adopted comprehensive plan; a Town, State or Federal park; property containing a conservation easement because of its visual beauty, land under conservation, or by a State or federal agency. (Vinalhaven Planning Board, 2001)

The question left unanswered by this wording is this: how is "unreasonable adverse impact" to be determined? Though the legal document attempts to lay down "factors of consideration" for the Planning Board in relation to scenic views, such as "the extent to which the proposed wireless telecommunications facility is visible above the tree line" and "the amount of vegetative screening", the fact remains that multiple stakeholders hold conflicting positions on what an appropriate boundary would be.

\section{Formation of concepts}

Thus, the analysis has identified the object in question within the discourse of the potential cell phone tower, explored the stakeholders and authorities involved in the discourse, and named some of the surfaces of emergence on which the discourse of the cell phone tower becomes knowable. Some of the ideas and issues underlying the discourse are coming to light. In this section, analysis of the formation of concepts reveals patterns of inclusion and exclusion, rules generating what is sayable (and therefore knowable) within the discourse. These rules dictate the structure of statements, which are the building blocks of the strategies discussed in the following section.

The discourse collected from The Wind, public letters, and planning board minutes reveal a web of concepts. The tower serves as a hinge for a series of discursive statements invoking or creating a boundary, structuring the discourse as a series of statements about connections or conditions pertaining to islandness. These material relationships are invoked by the rules of discourse produce a performative range of what Vinalhaven is seen to be and/or can be, each articulating a particular sense of 'Vinalhaven-as'. Thus, the community's place is not created by individual speakers, but rather through the discursive reality allowed by and through the discourse.

The statements regarding the cell phone tower consistently enact 'Vinalhaven-as': whether the speaker is for or against the cell phone tower. In other words, statements are often ordered in similar ways despite the speaker's position. Several statements ask implicitly or 
explicitly 'what kind' of Vinalhaven is desirable; demonstrating what Foucault (1972, p. 57) might term a "rhetorical schematic" designating "which groups of statements may be combined."

One example of this is what Chay-Nemeth (2001) terms "form of succession", or when two or more concepts are consistently or constantly linked. The best illustration I can provide is to share a narrative from one of my very first research trips to Vinalhaven:

It's a hot, sunny day in June of 2009. Though my car is parked meters from the shoreline in Rockland, there's no air coming off the water to cool those of us in line for the stateoperated, six-times daily ferry to Vinalhaven. With at least twenty cars, a pickup hauling a flatbed of hay, and a semi-truck in front of me, I'm sure I won't make the next ferry. The question is whether I'll make the last ferry of the day.

The ferry attendant is coming around to give good news to some, hopeful news to others, and bad news to the rest. I see him talking with two men near the back of a pickup. I stand up and lean against my car, listening at the ferry attendant tells them "it doesn't look good." He sees me, and shakes his head. "You might make it on, you've got a small car," he says. "But it's not looking good."

The younger of the two men shakes his head and looks at me and asks me what I'm going to the island for. "Research," I say. His eyebrows shoot up. "Oh? On what?"

"The cell phone tower discussion from a few years ago," I respond.

"Have you seen our windmills?" he says. I blink and shake my head no, the last time I had been on-island the construction of the three nearly 122-meter-tall windmills was barely underway. "You can see them from here," he continues, pointing out over the ocean toward the island. He shakes his head.

"You tell them we need that cell phone tower," the older man adds gruffly. "Can't get any service at all."

The anecdote above illustrates an interesting linking of concepts found several times within the data. Though it seemed a non sequitur when I first heard it, as soon as I would say I was interested in the proposed cell phone tower discussion from 2001, I would be asked or told about the windmills. Some of this patterning can be attributed to the fact that I was researching a decade-old public discussion on the cell phone tower, and the town's three 400-foot tall windmills were under construction, and later, in the early stages of operation. The windmills were the current hot topic. However, the more I experienced this linkage, the more I was sure there were connections beyond the fact that both projects were potential physical towers/columns debated by the community. As I learned more about the discourse surrounding the cell phone tower, and the community's attitudes toward the windmills, it became clear the non-existence of the cell phone tower is linked to the existence of windmill towers because the underlying discursive patterns (and associated values) are similar.

The windmills were the product of a US\$14.5 million community wind project, consisting of three 80-meter-tall windmills with 37-meter-long curved blades situated on one of the highest spots on the middle of the island (Waterman, 2009). The total height of the windmills reaches nearly 120 meters, more than twice as tall as the proposed cell phone tower.

To a certain extent, the discursive pattern similarities between the discourses of the cell phone tower and the windmills are superficial and self-evident. Both concern the construction of physical structures that protrude skyward; and both were discussed in terms of visual 
pollution. Yet the environmental impacts of the different structures were weighed differently. An island resident and self-identified transplant 'from away', Phil Crossman, served as a planning board member during the cell phone tower controversy. He confirmed that in both the cases of the cell phone tower and the windmills, the issue of bird strike deaths was discussed. Many of those opposing the cell phone tower used the issue of bird strikes as a potential legal way to gain traction against the construction of the tower. However, the issue was not discussed at length during the windmill planning stages, said Crossman.

Why, if bird strikes were raised as a significant issue against the cell phone tower, were they not raised substantively during the windmills issue? Whose values moderated the debates, and how do those values produce the island place of Vinalhaven?

From the early letters of the first days of the cell phone tower discussion, it is clear the initial objections to the cell phone tower were primarily about aesthetics and the loss of a 'way of life'. As the opposition progresses within the public documents, other concerns are raised, such as the environmental impact, the fiscal responsibility for the tower should it no longer be in use, and other more minor concerns. One possible analysis is that those defending the bird kill issue vociferously during the cell phone tower construction were much more restrained during the windmill discussion because they perceived the net environmental benefits of the windmills (clean energy, less reliance on polluting fossil fuels) outweighed the potential harm in terms of bird deaths.

However, there is another interpretation. It is possible that some of the groups of people who opposed the cell phone tower did so primarily for the reasons already laid out—namely the aesthetic issues, rooted in the idea of Vinalhaven as a bucolic, unspoiled, unique and pure place. As noted earlier, many of these people are not working-class. They are the financially mobile who choose and re-choose Vinalhaven as a vacation destination or second home out of many possible places. And, in the historical tradition of the early environmental movement, these are often the same groups of people who work to preserve nature for future recreation.

The environmental movement has its roots in the recreational habits of the upper class. Historically in the United States, the wealthy purchased tracts of land to preserve as recreational playgrounds. Throughout its development, the movement has continued to be associated with a white, middle- and upper-class population; though the movements' sociopolitical makeup has shifted dramatically over the past few decades as the environmental justice movement has exploded (Silveira, 2004). Many areas of Maine, particularly along the coast, have served as "summer retirements" for the wealthy from urban areas in other New England states (Lewis, 1993).

Another significant concept that developed during the discussion of the cell phone tower is that of Vinalhaven as a (potentially dangerous) place of isolation. Emergency Medical Technician Millie Martin (2001) writes a letter to The Wind, describing her experiences as a member of the ambulance crew, and states: "As a community we need to ban together and vote this tower through, once and for all! Knowing this tower could aide in saving a human life, how can we vote against it?"

For Martin, the proposed technology represents a connectivity associated with safety and wellbeing: a safer Vinalhaven. As Foucault (1972, p. 56) considers the "types of dependence of the statements", a patterning implicit in Martin's statement becomes clear: that a speaker's argument about or opinion on the question is dependent on a specific vision of a desirable 'Vinalhaven-as' and that concept of Vinalhaven is dependent (in part) on an element of connection or isolation. Though Martin's statement does not invoke a clear and obvious rigid 
ordering of a series as a natural history classification of genus, family, species within the statements, there is an implicit order of dependency of ideas.

In a similar vein to Martin, year-round resident Dana Barton (2001) writes in June of 2001 in The Wind:

This tower will greatly improve communication on Vinalhaven. Not only for the private person or the fisherman out on his boat, but also for our Fire Dept., Police Dept., Ambulance and Doctor [...] It's time we band together, islanders and supporters. Let's take our island back.

Again, Barton's statement depends on a desirable 'Vinalhaven-as' that is less isolated. Barton also touches upon another common element in the "field of presence" (Foucault, 1972, p. 57) -whether stated explicitly or not - the often-contentious relationship between year-round and summer residents.

Statements made within the discourse are, as a rule, associated with a speaker not as an individual, but as a representative of a larger group. It becomes nearly impossible to speak about Vinalhaven's potential cell phone tower without invoking the web of concepts associated with the speaker's identity category; indeed, they are a formative part of the field of presence. These particular elements of the field of presence, which first act as a concept-gathering apparatus, are also leveraged within the discourse as "interventions" (Foucault, 1972). The subject-position associated with a statement invokes a slew of values, issues and ideas; yet the way in which elements are linked within the statement "delimits once again — by extension or restriction - the domain of validity of statements" (Foucault, 1972, p. 59). In other words, a statement by a yearround resident invokes concepts and ideas related to 'year-roundedness', and the way in which the statement refers to the subject-position categories restricts or extends validity.

It is interesting that, whether a speaker is advocating for or against the cell phone tower, or whether the speaker posits that Vinalhaven is isolated or connected (and whether connectivity should be expanded), nearly every speaker desires to preserve Vinalhaven 'as it is'. Perhaps it would be more accurate to say that nearly all speakers and stakeholders seek to preserve Vinalhaven as they perceive it to be. This is especially striking since the goal of some is to introduce a new technology to the community, and for many others the urge to preserve the island comes from the dynamism of the 'real world'; in short, the only fixed place of 'Vinalhaven' exists within the consciousness of the individuals themselves.

\section{Formation of strategies}

Those who were opposed to the construction of the tower framed their strategies around the concept of the destruction of the uniqueness of Vinalhaven. Those who were for the tower primarily framed their strategy in terms of public health and safety. Both strategies hinged on the element of boundedness; one privileges the island's boundedness as a deterrent for contagion, the other privileges boundedness as a trial integral to community identity, yet to be mitigated as well as possible. Both might agree that the boundedness of Vinalhaven is a necessary part of the community's place. What is at stake in the formation of these strategies is not whether Vinalhaven as an island should be disconnected from the mainland; but rather how Vinalhaven is dis/connected; the reasons why the spaces are (or should be) distinct.

The strategies against the cell phone tower construct the potential tower as a force of destruction; whether of the environment, the values of the community, the aesthetic appeal of 
Vinalhaven, land values, or even public health. For instance, McCabe's (2001) letter explicitly rejects the cell phone tower and its attendant cell coverage as a 'mainland value': "An island by definition is a body of land surrounded by water [...] a world unto itself. Man has the ability to be a protector or destroyer of the fragile ecosystem of the island. [If] he destroys it [...] it will be gone forever".

Such strategies serve to promote the uniqueness of the island as a bounded entity. The boundedness of the island creates a space defined, for these summer residents, as anti- or notmainland. This 'not-mainland' is distinct from the mainland not just physically but emotionally, culturally, and mentally as well (Gillis, 2004). It is a complex relationship, one that evokes "lingering tensions in indeterminate spaces of movement/stasis, natural/corporeal, isolation/intimacy, migration/dwelling, home/away, placelessness/belonging” (Thomas, 2007, p. 23). Foucault (1986, p. 24) might conceive of Vinalhaven as a heterotopia, or a space of multiple and conflicting meanings. Particularly, we can understand Vinalhaven as a sort of mirror; a place that exists and is real, but is also unfixed and "absolutely unreal," reflecting this shifting reality.

As discussed above, the integral worth of the island for this group of stakeholders is its difference from the mainland. In this, there is much overlap with other stakeholders in the community, including year-round residents, with what Foucault (1972) would term links between discourses. Nearly every stakeholder group values the island as a place substantially different from the mainland. That difference is attributed most often to the island's geography. Yet, those who summer on or visit the island interpret Vinalhaven as an escape to the idyllic unreal; the mainland is where the 'real' world lives and visiting the island is special because it is beautiful, easy, and relaxing.

What becomes clear in examining the potential cell phone tower issue is that there is a general agreement on the necessity of boundedness for the maintenance of place. Indeed, the fact that Vinalhaven is bounded and enisled is an important aspect of the community's identity for multiple strategies, and an associated construct whether the discourse in question treats the potential tower favourably or unfavourably, and whether it comes from someone who is a yearround resident or a summer resident. There is also a vested interest by most parties, and a commonality in the discourse, to preserve and protect something inherent to the place of Vinalhaven, and a fear of loss of that something.

Repeatedly, as well, the discursive patterns reveal a set of fears about purity and contamination that have little to do with the technology itself. Discourse ostensibly revolves around the visual or environmental impact of the physical tower or the potential improvements to non-physical communication and improved connectivity. But, regulating that discourse is a series of concepts and objects revealing concern with the physical movement of bodies and those bodies' impact upon the place of Vinalhaven. Thus, the place of Vinalhaven is intertwined with the physical presence or movement of bodies and the spatial experience of those bodies.

\section{Discussion}

This project began with an interest in studying the relationship(s) between space/place and potential shifts in technology at the local, specific level. What began as a narrow, highly specific examination of one island community at its discursive intersect with a potential technology revealed a complex interrelationship of various narratives, values, and concepts: an interrelationship with potential applications and scholarship beyond the shores of Vinalhaven. 
The idea that the importance of place, the investment of affect in the specificities of a particular space, has waned with the advent and proliferation of new communication technologies (Meyrowitz, 1985) does not ring true within the discourses examined here. If anything, the potential or actual introduction to new or altered forms of connectivity prompted the articulation of a salient, clear, 'placial' identity. In particular, the potential increased connectivity urged a re-affirmation of place. It seems that, in these cases, a change in technology brings to attention the community's multiple boundaries. These boundaries (physical, social, and other) are the points of negotiation and iteration for community identity. Once brought to attention by the change or potential change, public discourse becomes the site of place affirmation and negotiation. And, as communication technologies increase the visibility of boundaries and their permeation, the technologies are often sites of conflict and fear within discourse.

Likewise, the study reveals the necessity of understanding any shift in technology affecting connectivity as context with/in the place where it is to be introduced or changed. This is because, as we have seen in Vinalhaven's case, the technology itself is often not the nexus of the public discourse, but rather what that technology means for, to, and in Vinalhaven. Thus, understanding a technology must be about recognizing that it is not about what a technology can do, but what it can do in, to and for a particular place. This requires a nuanced, case-by-case approach to understanding the relationships between community and technology.

Without being flippant, the bottom line is that place continues to matter, both in terms of affect and attachment and in the physical sense. Examining the island's public discourse from the early 2000s revealed multiple articulations of spatial narratives of belonging, each concerned with boundaries and potential contamination. The discourses of boundedness were linked repeatedly to the concept of preservation of place, as perceived by those participating in the discourse. Part of the duality of place, the ongoing dynamic reaffirmation of an identity prized often for its immutability, is its ongoing reiteration. This process is constant, but not always visible; the multiple trajectories of place are often unnoticed precisely because they are understood as part of the immutable 'nature' of a place. These trajectories - what a locale currently is, where it projects-become visible only when there exists a "clash of trajectories" (Massey, 2005, p. 156).

One of the more surprising elements of the analysis was the complex and multiple articulations of social class as an organizing element. While I had expected there to be some emphasis on the role of class in a discussion of a community where there are economic gaps between the primarily working-class year-round residents and the summer residents who generally are more affluent, class revealed itself in unexpected ways. The substantial role of class in these discourses surrounding technology use links this study to a larger arc within technology studies regarding accessibility of technology. Much work has been done about access to technology and the issue of the 'digital divide' (Rogers, 2001; Norris, 2001). That work has its own shortcomings and gaps, including how scholars should define and interrogate the construct of the digital divide (Selwyn, 2004). What this study demonstrates is that any attempt to analyse the relationship between a community and its technologies must account for varying socioeconomic circumstances as a potentially rich source of insight. Place means something different, even in dialogue about the same technology within the same community, depending on the means available to the person in question, and how those means shape the desirability of certain traits of the community. While the fundamental processes of boundary negotiation, affirmation, and preservation are remarkably similar regardless of socioeconomic status, the concepts used within the discourse vary widely according to that status. 
Thus, technology is best examined in a place-based context because it operates in a place. Specifically, researchers should attend to the discourse of place not because it is a separate element that needs to be considered as a part of the potential or actual deployment of a technology but because the discourses of technology are an inseparable and fully integrated part of the discourses of place. The conversation about digital technologies cannot occur in a research vacuum from other technologies. The assumption that there is something unique or singular about digital technologies is a seductive fiction that must be avoided by those who study the human-technology relationship. Every technology is deployed in an extant, dynamic web of place. This extant web of place includes a collection of interacting technologies couched in particular bodily habits and identity expressions. Therefore, expecting the introduction of a new or changed technology (particularly one that impacts the permeation of a community's boundaries) to have the same effect in Vinalhaven as it does elsewhere is to ignore the complex nest of technologies that already exist, and how those extant technologies are engaged in the discourses of place.

\section{Conclusion}

This study offers substantive groundwork for the development of a policy or program framework to guide the introduction or substantive change of technology within a bounded, island community: consider how some governmental or grant-funded programs seek to increase technological access to rural, isolated communities; or how NGOs seek to introduce new communication or other connective technologies to disparate communities in underdeveloped countries. This framework might include guidelines to potential researchers or program directors of questions to ask, issues to identify and keep in mind, and suggestions for background knowledge related to a particular introduction of technology.

Another avenue for further research could be comparative research between relatively isolated island communities such as rural islands and heterogeneous or fluid communities that are 'hyper' connected, such as urban island centres. Urban island centres offer their own locus of study (Grydehøj et al., 2015). There are potential parallels between the two distinct types of island communities in relation to the experience of space. It is worth asking whether hypermobility and hyper-connectivity may be (as?) integral to the experience of place as the lack of connectivity or introduction of increased connectivity. For instance, hypermobility and connectivity relies heavily on a well-informed sense of location in relation to multiple networks; consider how displaced people feel when Internet or mobile technologies are malfunctioning or unavailable.

This study foregrounds the centrality of islands as sites of study. In this particular case, Vinalhaven's boundedness emphasizes the condition of being an island in light of proposed technological change. As with so many studies of islands, its findings are applicable in a wide range of disciplines and settings. This study also deepens the understanding of place-related identity within island studies. Particularly, it furthers the work of Hay (2006), broadening our understanding of the experience of island life and the development of islands as places.

\section{References}

Baldacchino, G. (2005). Islands: objects of representation. Geografiska Annaler B: Human Geography, 87(4), 247-251. https://doi.org/10.1111/j.0435-3684.2005.00196.x

Barton, D. (2001, June 20). The Wind. Cell phone users take notice [Opinion]. Vinalhaven Historical Society Archives. Vinalhaven, ME. 
Brown, B., \& Brown, P. (2001, August 29). The Wind. The debate over a cellular phone tower [Opinion]. Vinalhaven ME: Vinalhaven Historical Society Archives.

Chay-Nemeth, C. (2001). Revisiting publics: a critical archaeology of publics in the Thai HIV/AIDS issue. Journal of Public Relations Research, 13(2), 127-161. https://doi.org/10.1207/S1532754XJPRR1302_2

Crossman, P. (2009, August 4). Personal interview.

de Certeau, M. (1984). The practice of everyday life. Berkeley CA: University of California Press.

Douglas, M. (1966). Purity and danger. New York: Routledge. https://doi.org/10.4324/9780203361832

Dreyfus, H. and Rabinow, P. (1983). Michel Foucault: Beyond structuralism and hermeneutics. Chicago IL: University of Chicago Press.

Fitchen, J. (1991). Endangered spaces, enduring places: Change, identity, and survival in rural America. New York: Oxford Westview Press.

Foucault, M. (2007). Security, territory, population. G. Burchell, (Trans.). New York: Picador. Original work published in 2004.

Foucault, M. (1994). The order of things. Originally work published in 1971. New York: Vintage.

Foucault, M. (1986). "Des espaces autres" (Of other spaces: Utopias and heterotopias). J. Miskowiec (trans.) Diacritics, 16(1), 22-27. https://doi.org/10.2307/464648

Foucault, M. (1972). The archaeology of knowledge and the discourse on language. New York: Pantheon.

Gibbons, M.S. (2010). Islanders in community: Identity negotiation through sites of conflict and transcripts of power. Island Studies Journal, 5(2), 165-192.

Gillis, J. (2004). Islands of the mind: How the human imagination created the Atlantic world. New York: Palgrave Macmillan.

Grydehøj, A. Pinya, A. Cooke, G. Dorath, N. Elewa, A. Kelman, I. Pugh, J. Schick, L. \& Swaminathan, R. (2015). Returning from the horizon: Introducing Urban Island Studies. Urban Island Studies 1(1), 1-19. https://doi.org/10.20958/uis.2015.1

Grosz, E. (2001). Architecture from the outside. Cambridge, MA: MIT Press.

Hall, C.M. (2005). Tourism: Rethinking the social science of mobility. London, U.K.: Pearson Education Limited.

Hall, C.M. \& Muller, D. (Eds.) (2004). Tourism, mobility, and second homes: Between elite landscape and common ground. Tonawanda, NY: Channel View Publications.

Hall, C.M. \& Williams, A. (2008). Tourism and innovation. New York, NY: Routledge.

Hay, P. (2006). A phenomenology of islands. Island Studies Journal, 1(1), 19-42.

Karampela, S. Kizos, T. \& Spilanis, I. (2014). Accessibility of islands: towards a new geography based on transportation modes and choices. Island Studies Journal, 9(2), 293-306.

Lamprecht, A. (2001, July 18). The Wind. Proposed cell phone tower [Opinion]. Vinalhaven Historical Society Archives. Vinalhaven, ME.

Lewis, G.H. (1998). The Maine lobster as regional icon: Competing images over time and social class. In B. G. Shortridge \& J. R. Shortridge (Eds.), The taste of American place (pp. 6584). Lanham, MD: Rowman \& Littlefield.

Lewis, G.H. (1993). The Maine that never was: the construction of popular myth in regional culture. Journal of American Culture, 16(2), 91-100. https://doi.org/10.1111/j.1542734X.1993.00091.x

Mackenzie, A.F.D. (2004). Place and the art of belonging. Cultural Geographies 11(1), 115-137. https://doi.org/10.1191/1474474004eu295oa 
MacQuestion, C. (2001, February 8). [Letter to Planning Board on proposed cell phone tower]. Planning Board records, Town of Vinalhaven, Vinalhaven, ME.

Martin, M. (2001, October 10). The Wind. Help us [Opinion]. Vinalhaven ME: Vinalhaven Historical Society Archives.

Marshall, J. (2009). Tides of change on Grand Manan Island: Culture and belonging in a fishing community. Montreal: McGill-Queen's University Press.

Massey, D. (2005). For space. Cambridge: Polity Press.

McCabe, M. (2001, February 9). [Letter to Code Enforcement Officer on potential cell phone tower]. Planning Board records, Town of Vinalhaven, Vinalhaven, ME.

McCall, G. (1994). Nissology: a proposal for consideration. Journal of the Pacific Society, 6364(17), 99-106.

McCall, G. (2002). Nissology: something to think about and something to protect; beyond the boundaries. Proceedings of the IUCN/WCPA-EA-4 Conference: Conference on the Protected Areas of East Asia. Taipei, Taiwan.

McReynolds, S.A. (2014). Community sustainability in the year-round islands of Maine. Island Studies Journal, 9(1), 79-102.

Meyrowitz, J. (1985). No sense of place: The impact of electronic media on social behaviour. Oxford: Oxford University Press.

Norris, P. (2001). Digital divide: Civic engagement, information poverty, and the Internet worldwide. Cambridge: Cambridge University Press. https://doi.org/10.1017/CBO9781139164887

Persoon, G.A., \& Osseweijer, M. (2002). Small island and small island societies in theory and practice: Two Indonesian cases compared. In H.H. Hsiao, C.H. Liu, and H.M. Tsai (Eds.), Sustainable development of island societies: Taiwan and the world (111-136). Taiwan: Asia-Pacific Research Program.

Rogers, E.M. (2001). The digital divide. Convergence, 7(4), 96-111. https://doi.org/10.1177/135485650100700406

Selwyn, N. (2004). Reconsidering political and popular understandings of the digital divide. New Media \& Society, 6(3), 341-362. https://doi.org/10.1177/1461444804042519

Silveira, S. (2004). The American environmental movement: Surviving through diversity. Boston College Environmental Affairs Law Review, 28(2), 497-532.

Thomas, J. (2011, December 22). Farmer Brown's lawyer says settlement with state unlikely. The Weekly Packet, p. 1.

Thomas, S. (2007). Littoral space(s): liquid edges of poetic possibility. Journal of the Canadian Association for Curriculum Studies, 5(1), 21-29.

Thompson, C.R.S. (2012). "Gentrification and Vulnerability of Maine Fishing Communities" University of Maine Electronic Theses and Dissertations. Paper 1860.

Vinalhaven Planning Board (2001). Wireless telecommunication facilities ordinance. Planning Board records, Town of Vinalhaven, Vinalhaven, ME. Available: http://townofvinalhaven.org/ordinances/Land Use Ordinance.1.pdf

Waterman, M. (2009, November 12). Up and turning on Vinalhaven. The Free Press. Retrieved from: www.freepressonline.com/main.asp?SectionID=52\&SubsectionID=78\&ArticleID=3834 